\title{
A degradação social do trabalho e da natureza no contexto da monocultura canavieira paulista $^{1}$
}

MARIA APARECIDA DE MORAES SILVA" RODRIGO CONSTANTE MARTINS"

\section{Resumo}

O objetivo deste artigo é discutir a dinâmica sócio-ambiental da moderna agricultura sucroalcooleira. O texto desenvolve uma análise concreta do fenômeno do agronegócio, resgatando as relações significativas que lhe dão sentido concreto isto é, que lhe conferem posição compreensiva na unidade do diverso. Para tanto, são abordadas as dimensões de exploração do trabalho social e dos recursos naturais no âmbito deste fenômeno - com ênfase no caso da região de Ribeirão Preto, interior do Estado de São Paulo. As conclusões do estudo indicam: a) as relações autoritárias que compõem o fenômeno estudado, próximas daquelas descritas por M. Weber em sua interpretação do capitalismo Junker alemão e; b) a necessidade de articulação das esferas social e ambiental nas análises dos processos de acumulação no campo, desvendando as dimensões materiais e simbólicas que amparam a modernização conservadora representada pelo agronegócio no Brasil.

Palavras-chave: Trabalho Rural. Agricultura e Meio Ambiente. Trabalho e Meio Ambiente.

\footnotetext{
* Socióloga. Doutora em Sociologia do Desenvolvimento pela Université de Paris I (Panthéon-Sorbonne). Professora livre-docente da UNESP, colaboradora do Programa de Pós-graduação em Geografia/UNESP/PP e do Programa de Pós-graduação em Sociologia da UFSCar. Pesquisadora CNPq. ** Sociólogo. Doutor em Ciências da Engenharia Ambiental (área: sociologia ambiental) pela USP, com pós-doutorado em Sociologia pela École de Hautes Études en Sciences Sociales de Paris. É Professor do Programa de Pós-graduação em Sociologia da UFSCar.

1 A realização deste trabalho contou com suporte financeiro do Conselho Nacional de Desenvolvimento Científico e Tecnológico (CNPq) e da Fundação de Amparo à Pesquisa no Estado de São Paulo (FAPESP).
} 


\section{Introdução}

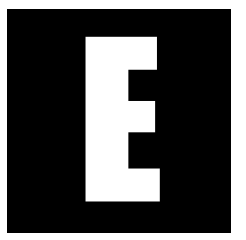

m conferência realizada em St Louis (EUA) em 1906 por ocasião de um Congresso de Artes e Ciências, Max Weber empreendeu uma marcante interpretação da expansão do capitalismo moderno nas áreas rurais da Alemanha². Estabelecendo as características históricas entre os diferentes tipos de capitalismo consolidados nos campos do leste e do oeste alemão, bem como suas distinções em relação à experiência norte-americana, o autor destacava a variedade de racionalidades, as especificidades dos casos alemães e, sobretudo, o caráter autoritário do capitalismo constituído ao leste do Elba, em termos de sentido das ações das elites agrárias e de estrutura social.

Nesta interpretação weberiana, a melhor representação deste capitalismo autoritário no leste alemão seria a figura do Junker prussiano. Diferentemente do fazendeiro-empreendedor norte-americano, o Junker estaria menos interessado na racionalidade técnica do uso da terra, na organização da produção e na administração da agricultura como um negócio-tipo capitalista do que na manutenção de sua posição social, seu prestígio através da posse da terra e do controle das ações do Estado, mantendo inclusive a interferência direta no recrutamento das fileiras burocráticas deste último. Assim, as transformações na agricultura do leste do Elba - ou, nos termos de Weber (1982), as metamorfoses da economia Junker - não possuíam um sentido ideal-capitalista, embora tenham transformado o Junker, cujo sonho seria o de ser um eterno senhor feudal, em empresário capitalista. Seus interesses agrícolas e imobiliários resultariam

2 Esta conferência intitulada The relations of the Rural Community to other Branches of Social Science encontra-se traduzida em língua portuguesa sob o título Capitalismo e Sociedade Rural na Alemanha. A propósito, ver Weber (1982). 
no despovoamento do leste alemão, área outrora densamente povoada por camponeses. Neste movimento, o Junker, figura contraditória entre o tipo capitalista puro e a tradição, atraía trabalhadores temporários da Polônia que, em virtude de seus baixos padrões de vida e da aceitação dos altos níveis de exploração do trabalho, característicos da estrutura agrária Junker, migravam e acabavam por contribuir para a desagregação do campesinato no leste alemão.

Esta breve introdução aos conflitos da sociedade rural alemã do século XIX parece-nos apropriada para a introdução de um estudo sobre o desenvolvimento recente do agronegócio sucroalcooleiro no Brasil. Sobre bases sociais distintas, é possível identificar pelo, menos três características da economia Junker no desenvolvimento desta moderna agroindústria em certas regiões do país: sua marca de modernização conservadora, que sustenta importantes contradições fundiárias com base na força de classe dos grandes proprietários rurais; suas relações com o Estado, baseadas no patrimonialismo e na naturalização das desigualdades sociais e seu caráter autoritário, expresso, por exemplo, nas relações mantidas pelas usinas de açúcar e álcool com seus trabalhadores e mesmo com as instituições de regulação social e ambiental das atividades do setor.

Desde meados da década de 1990, a forma de apresentação dos números acerca do aumento da produção e da produtividade de grãos tais como soja, café, algodão, cana-de-açúcar, bem como os derivados como álcool e suco de laranja, vêm sendo decisiva na consolidação dos olhares da sociedade brasileira sobre o agronegócio. Neste início de século, as promessas de sustentabilidade sócio-ambiental presentes na discussão abstrata sobre os biocombustíveis seguem reiterando as marcas de desenvolvimento econômico que os agentes do agronegócio trazem para si. Todavia, os chamados índices de modernização, ao serem amparados pela lógica conservadora, patrimonial e autoritária própria da economia 
Junker, são também acompanhados de desemprego, de precarização das relações de trabalho e graves impactos ambientais.

O objetivo deste texto é contribuir para as reflexões referentes às formas de reprodução desse modelo de agricultura, cujos valores simbólicos e características de produção indicam tensões sociais que são, simultânea e contraditoriamente, novas e conservadoras. Para tanto, buscaremos desenvolver uma análise concreta das repercussões sociais e ambientais do referido modelo. Esta análise visa justamente superar a possibilidade de uma interpretação abstrata do fenômeno do agronegócio, resgatando as relações significativas que dão sentido concreto (como unidade do diverso) às dimensões de exploração do trabalho social e dos recursos naturais no âmbito do processo de produção de valor. Assim, para construir o concreto pensado nos termos propostos por Marx (1987), interpretaremos inicialmente as formas mais gerais dos processos de degradação ambiental e precarização das relações de trabalho neste modelo de agricultura. Para tanto, retomaremos dados dos contextos nacional e paulista, dando ênfase ao caso da região de Ribeirão Preto. Posteriormente, aprofundaremos a discussão sobre os elementos visíveis e invisíveis que caracterizam a complexidade do trabalho social na agricultura da região, bem como as forças sociais que atuam no campo das lutas.

Para a análise dos impactos ambientais da moderna produção agroindustrial, partir-se-á do pressuposto sugerido por Martins (2004), de que a relação sociedade-natureza é regulada menos por ações institucionais do que pelas disputas entre grupos e classes sociais em busca da hegemonia nas formas de uso e apropriação dos recursos. Nesta perspectiva, do ponto de vista analítico, os processos ecológicos circunscritos aos ambientes de produção de valor adquirem um conteúdo histórico que ultrapassa a simples condição de base biofísica dos processos de acumulação. Deste conteúdo histórico são parte as ações institucionais de política ambiental que refletem tanto as 
pressões de setores da sociedade civil em prol das modernas causas ambientais, bem como a força política dos grandes grupos econômicos sobre setores distintos da administração pública (este é o caso, por exemplo, das legislações estaduais e federal sobre a prática das queimadas na agricultura).

$\mathrm{Na}$ análise das relações de trabalho, a noção de labor, proposta por Arendt (2005), será particularmente interessante para analisarmos as implicações das modalidades de exploração da força-de-trabalho nos canaviais da região. Partindo de uma revisão crítica sobre a dimensão relacional da categoria trabalho em Marx, Arendt (2005) estabelece a distinção de três momentos no curso deste movimento de formação, quais sejam, o labor, o trabalho e a ação. O labor se referiria, na perspectiva da autora, às atividades fundamentais do ser humano sobre a natureza, provendo suas condições de existência orgânica. O trabalho diria respeito ao exercício de dominação do indivíduo sobre a natureza, onde a atividade teleológica orientaria a criação e o emprego de técnicas de transformação socialmente condicionada do ambiente natural. A ação, por sua vez, designaria quadros de referência onde o indivíduo transcenderia sua condição de trabalhador em, direção à política em sentido amplo. Este seria o momento da construção de ambientes para a experimentação de outras esferas de sociabilidade, de tal sorte que as barreiras da natureza ao labor seriam socialmente contornadas e o universo das técnicas de trabalho seria politicamente direcionado para a promoção do domínio da liberdade. Neste esforço, pretende-se, por fim, demonstrar como estas dimensões - a social e a ambiental - são indissociáveis do ponto de vista das análises dos processos de acumulação.

\section{Produção de valor excedente e degradação ambiental}

Base técnica sobre a qual o capital industrial assentou suas relações com a agricultura no curso do século XX, a chamada Revolução Verde no Brasil caracterizou-se fundamentalmente pela prática de uma agricultura 
altamente especulativa, voltada para o cultivo contínuo de produtos com maiores níveis de rentabilidade. Tal característica foi fundamental para consolidar a monocultura - em detrimento dos sistemas de rotação - como elemento de destaque nas estruturas agrárias não apenas do Brasil, mas de todos os países tropicais influenciados pelo referido modelo (GOODMAN; REDCLIFT, 1991). Além disso, a adoção dos agroquímicos como reposta tecnológica ao esgotamento do solo e à infestação de pragas geradas pela própria monocultura resultou, sobretudo nestes países, em índices ainda mais elevados de perdas de fertilidade e estabilidade física do próprio solo.

No caso brasileiro, os riscos ecológicos próprios dos componentes do moderno pacote tecnológico, somados ao descontrole do receituário agronômico da maioria das propriedades agrícolas, provocaram - e continuam a provocar - danos ecossistêmicos irreversíveis em algumas regiões do país. O uso intensivo de fertilizantes, por exemplo, é um dos fatores fortemente associados à eutrofização dos rios e lagos, à acidificação dos solos e à contaminação de aquíferos. Dados do Instituto Brasileiro de Geografia e Estatística dão conta de que, no Brasil, em 1992 foram comercializados $69,44 \mathrm{~kg} / \mathrm{ha}$ destes compostos para fins agrícolas; em 2000, este montante chegou a $128,83 \mathrm{~kg} / \mathrm{ha}$, o que equivale a um crescimento médio de $85,5 \%$ no volume de fertilizantes utilizados por hectare plantado. Estes números ganham ainda maior expressão se observarmos que o crescimento de área plantada no país, neste mesmo, período girou em torno de 23\% (FIBGE, $2002)^{3}$. Já no caso dos agrotóxicos - componente altamente danoso tanto ao ambiente natural quanto à saúde humana -, a quantidade comercializa-

3 Este aumento desproporcional do uso de fertilizantes em relação ao crescimento da área plantada tem sido verificado em toda a América Latina e Caribe. Dados da Cepal (Comisión Económica para América Latina y El Caribe) mostram que nesta região, entre os anos de 1990 e 1998, a área agrícola cresceu 6,3\%, enquanto o consumo total de fertilizantes cresceu 42,2\% (CEPAL, 2002). Ademais, a Cepal destaca ainda que o que poderia significar a disseminação de técnicas modernas de plantio guarda especificidades perversas na América Latina, posto que mesmo a expansão da fronteira agrícola na região segue historicamente atrelada às tendências de especialização agrícola (tendo em vista os mercados externos) e o monocultivo. 
da no país passou de 2,27kg/ha em 1997 para 2,76 kg/ha em 2000, correspondendo a uma elevação de $21,6 \%$ na quantidade aplicada por hectare.

No Estado de São Paulo, as perdas anuais de solos em algumas áreas de lavouras tradicionais - como o feijão, o milho e a cana-de-açúcar - por manejo inadequado do solo, chegaram, no final da década de 80, ao patamar dos 60 mil hectares (LAMBERT, 1990). Em 1995, Bastos Filho (1995) alertava que cerca de 15 milhões de hectares, ou $80 \%$ da área cultivada no Estado de São Paulo, estariam sofrendo processos erosivos além dos limites técnicos de tolerância. Segundo o autor, um dos fatores determinantes para a extensão desses processos seria exatamente a ação antrópica, por via da remoção da vegetação natural, pela movimentação sobre o solo com maquinário pesado e pela aplicação excessiva de fertilizantes e corretivos agrícolas.

Estima-se que a erosão no Estado carreia para os corpos d'água superficiais cerca de 130 milhões de toneladas de solo por ano, provocando o assoreamento de rios, de várzeas e de reservatórios, além também de desencadear processos de eutrofização destas águas (COSTA; MATOS, 1997). Além da erosão, o mau emprego das técnicas de irrigação também tem provocado a contaminação dos recursos hídricos do Estado, através do carreamento dos resíduos de agroquímicos para as águas. A própria aplicação destes agroquímicos sobre o solo também tem gerado efeitos danosos, tanto ao meio ambiente (como à microfauna terrestre) quanto à saúde dos trabalhadores rurais. Segundo o Instituto de Economia Agrícola de São Paulo, 57\% dos aplicadores paulistas não recebem qualquer tipo de orientação, estando assim distantes de quaisquer normas e critérios de segurança (PNUD, 1999).

A partir da década de 70, a adoção em larga escala das práticas tecnológicas da Revolução Verde propiciou, de fato, a elevação dos níveis de produtividade em quase todas as culturas lavroeiras do País. Neste período, a política agrícola nacional, reforçando seu viés setorial e reiteran- 
do os interesses de classe, orientou-se para o setor externo estimulada por uma política cambial agressiva, levando com isso grandes produtores a transferirem recursos alocados na produção doméstica para o investimento em produtos exportáveis. Muito do estímulo governamental encontrou reverberação nos produtores paulistas, que passaram a dedicar-se às culturas mais "protegidas" pelo Governo - como foi o caso da monocultura canavieira, fortemente amparada pelo Pró-álcool.

Segundo dados do IEA (Instituto de Economia Agrícola), as regiões de Araraquara, Franca, Jaboticabal, Jaú, Limeira, Piracicaba, Ribeirão Preto e São João da Boa Vista, em 2006, tinham 1.342.607 ha com canade-açúcar. Neste mesmo ano, para o conjunto dessas regiões, houve um aumento de 451. 128 ha ocupados por este produto. Esta mesma fonte apresenta para o período 2006/2007 a diminuição de áreas de 32 produtos agrícolas, dentre eles: arroz (-10\%), feijão (-13\%), milho (-11\%), batata $(-14 \%)$, mandioca $(-3 \%)$, algodão $(-40 \%)$, tomate $(-12 \%)$, sem contar a redução de mais de 1 milhão de bovinos e a queda da produção de leite.

Sem embargo, a paisagem regional encontra-se fortemente marcada pelos impactos ambientais, decorrentes da expansão destes números, signos da intensificação do desenvolvimento do modelo euroamericano de modernização da agricultura. Os impactos relacionados à monocultura canavieira hoje integram o espaço regional ${ }^{4}$, revelando-se, por exemplo, através da intensidade do uso dos recursos hídricos na bacia hidrográfica da qual o município de Ribeirão Preto faz parte - qual seja,

4 A noção de espaço empregada neste estudo baseia-se na definição de Santos (1996, p. 26-27), para quem o "espaço não é coisa, nem um sistema de coisas, senão uma realidade relacional: coisas e relações juntas. Eis por que sua definição não pode ser encontrada senão em relação a outras realidades: a natureza e a sociedade, mediatizadas pelo trabalho. [...]. O espaço deve ser considerado como um conjunto indissociável de que participam, de um lado, certo arranjo de objetos geográficos, objetos naturais e objetos sociais e, de outro, a vida que os preenche e os anima, ou seja, a sociedade em movimento. O conteúdo (da sociedade) não é independente da forma (os objetos geográficos), e cada forma encerra uma fração do conteúdo. As formas, pois, têm um papel na realização social". 
a Bacia do Rio Pardo. De acordo com o Plano de Bacia do Comitê da Bacia Hidrográfica do Rio Pardo (CBH-Pardo), no concernente às captações superficiais cadastradas das águas na região, há ampla predominância de captação por porte de usuários industriais (mais de 80\% das captações superficiais cadastradas). Dentre estes usuários industriais, destacam-se as grandes usinas de açúcar e álcool que, de acordo com o próprio Plano de Bacia, "merecem atenção dos gestores não somente pela grande quantidade de água a ser disponibilizada (para suas atividades), mas também pelo fato de que parcela dos lançamentos não-contaminados chega aos cursos d'água com temperaturas não ambientes, pois são águas também utilizadas nos processos industriais" (CBH-Pardo, 2003, p. 59). Do ponto de vista ecológico, a diferença de temperatura entre as águas em curso na bacia e aquelas lançadas pelas unidades agroindustriais pode implicar em expressivos impactos para o ecossistema aquático como um todo.

Quanto às águas subterrâneas, o Plano de Bacia destaca a ausência de dados confiáveis sobre as captações efetivamente realizadas em toda a região. De acordo com o Plano, tanto os dados referentes ao abastecimento doméstico privado quanto aqueles relativos à irrigação e ao uso rural estariam fortemente subestimados no atual sistema de cadastramento de captações do DAEE. Todavia, mesmo considerando tal subestimação, o balanço hídrico da bacia revela dados alarmantes, cujas projeções apontam para a intensificação do processo de sobre-exploração das águas regionais - processo este já instalado desde 2003 (São Paulo, 2000).

Ainda sobre o uso das águas subterrâneas, o Plano de Bacia do $\mathrm{CBH}$ Pardo chama atenção para o nível de vulnerabilidade das reservas disponíveis na região. Isso considerando ao menos dois fatores. O primeiro deles diz respeito à alta exploração estimada dos recursos. O segundo refere-se à situação geográfica destas reservas d'água, o que inclui sua distância da superfície. A adubação, seja ela química ou orgânica, em solos 
com lençóis de águas rasos é problemática, justamente por seu potencial de poluição. No caso da cana-de-açúcar, a fertilização baseada no uso da vinhaça pode tornar-se altamente impactante aos corpos d'água em geral e aos aqüíferos em particular justamente em razão de sua elevada demanda bioquímica de oxigênio e de seu elevado conteúdo de nutrientes (FRAGA; ABREU; MENDES, 1994) $)^{5}$.

Ainda em relação às águas subterrâneas, os riscos do tipo de exploração do solo são particulamente graves na monocultura canavieira em razão, dentre outros, da intensidade do uso de herbicidas. Todos estes fatores de risco ambiental, próprios da cultura canavieira adquirem um conteúdo exponencial na região de Ribeirão Preto, justamente por sua localização fisiográfica. Como nos mostra a figura 1, a região está localizada sobre o Aqüífero Guarani, uma das principais reservas subterrâneas de água doce do mundo. A região situa-se, mais precisamente, na área onde a distância do aqüífero para a superfície do solo é uma das menores de toda sua extensão. A distância do município Ribeirão Preto para as águas do aqüífero varia de 150 a 300 metros; Sertãozinho está a cerca de 340 metros do aqüífero (ROCHA, 1997) ${ }^{6}$. A figura 2, por sua vez, destaca os atuais níveis de vulnerabilidade destas reservas subterrâneas em toda a bacia hidrográfica, revelando a incidência de maior comprometimento nas áreas do entorno do município de Ribeirão Preto, sabidamente ocupadas por usinas de açúcar e álcool e lavouras de cana.

\footnotetext{
5 Resíduo do processo de destilação do álcool, a vinhaça é gerada na proporção de 10,3 a 11,9 litros para cada litro de álcool produzido. Dentre suas características físico-químicas, estão a temperatura elevada (em torno de 35 graus), o pH ácido, a corrosividade, o alto teor de potássio e a quantidade crescente de nitrogênio, fósforo, sulfatos e cloretos (ANDRADE; DINIZ, 2007). 6 Os demais municípios do Estado de São Paulo, com superfícies próximas do Aqüífero Guarani, são Bauru (180-470 metros), Araraquara (250-400 metros), Jaú (530-550 metros), Monte Alto (660-708 metros) e São José do Rio Preto (10080-1380 metros).
} 


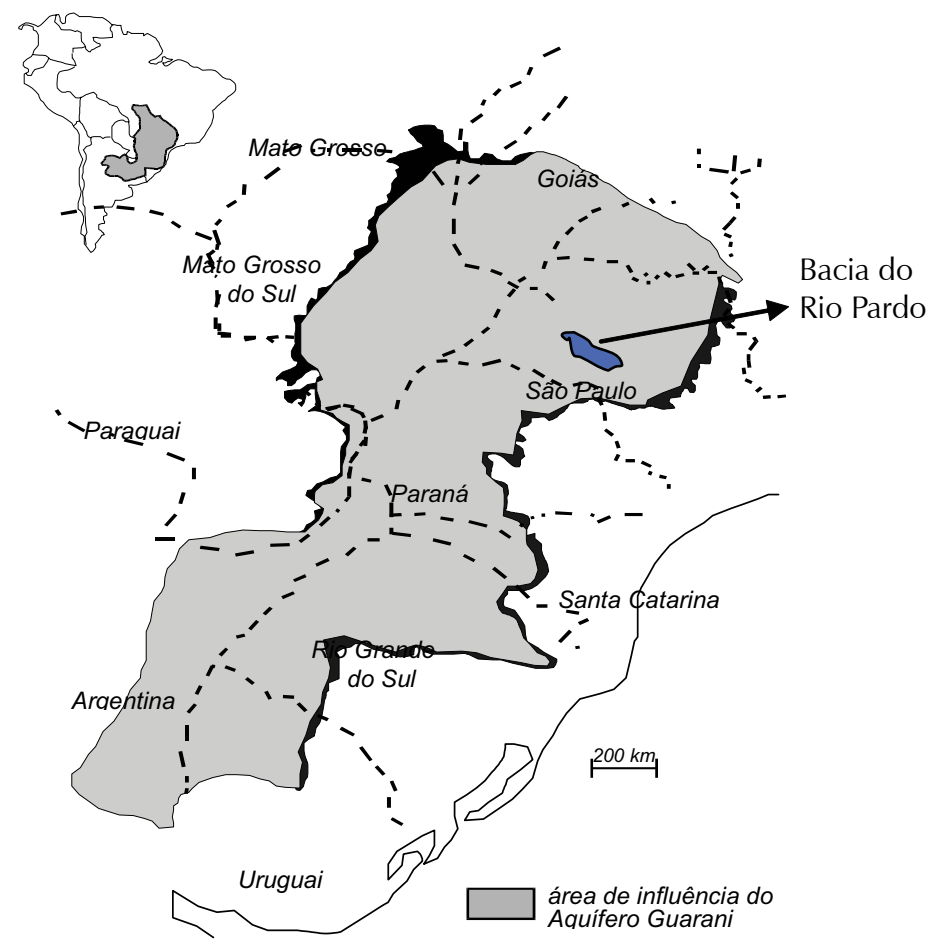

Figura 1. Posição geográfica da bacia do rio pardo no aquífero guarani.

Fonte: Universidade de São Paulo. Aquífero Guarani: um deserto com água. Estação Ciência; Instituto de Geociências, abril de 2005 


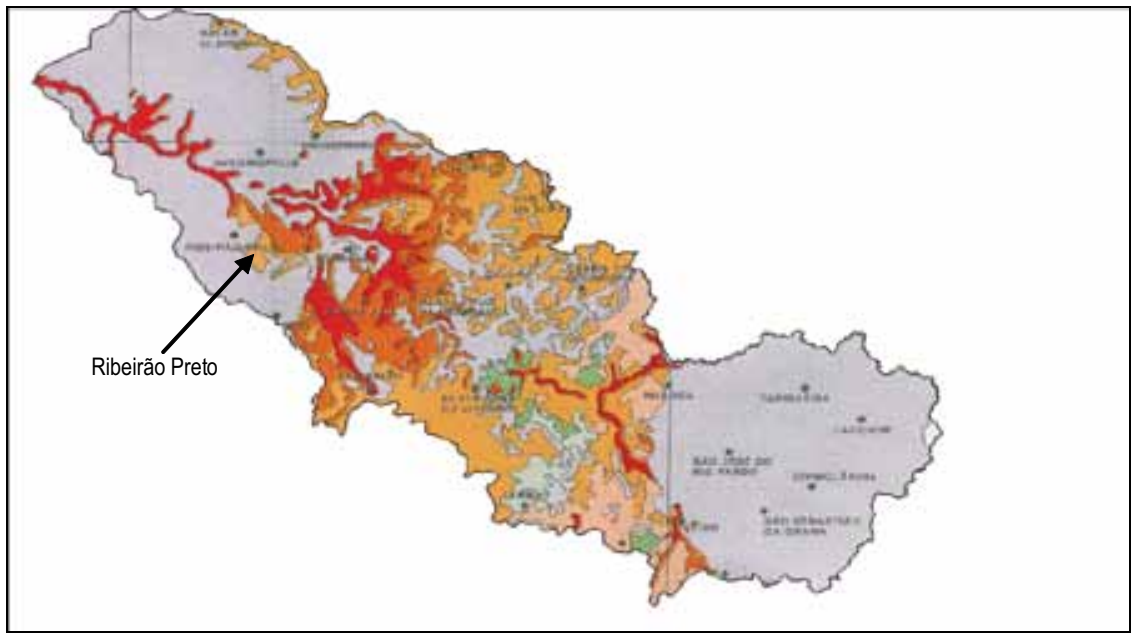

\begin{tabular}{||c|c|l|l|l|l|l|}
\hline \multirow{2}{*}{ NEFIO } & \multicolumn{2}{|c|}{ BADCO } & \multicolumn{2}{c|}{ MÉDIO } & \multicolumn{2}{c|}{ ALTO } \\
\cline { 2 - 7 } & RADCO & ALTO & BADCO & NLTO & BADCO & NLTO \\
\hline & & & & & & \\
& & & & & & \\
\hline
\end{tabular}

Figura 2. Mapa de vulnerabilidade das águas subterrâneas da bacia do rio pardo

Fonte: Plano de Bacia da Unidade de Gerenciamento de Recursos Hídricos do Rio Pardo. Relatório Final. Comitê de Bacia Hidrográfica do Pardo - CBH-Pardo: Realização: CPTI - Cooperativa de Serviços e Pesquisas Tecnológicas e Industriais; IPT - Instituto de Pesquisas Tecnológicas do Estado de São Paulo, 2003. 
A exploração intensiva do solo agrícola na bacia, pela monocultura canavieira, também segue comprometendo a qualidade do solo na região. Em 2003, da área total da bacia (que abrange $8.991,02 \mathrm{~km}^{2}$ ), pouco mais de $51 \%\left(4.643,09 \mathrm{~km}^{2}\right)$ apresentava processos erosivos (CBH-Pardo, 2003). A queimada da cana-de-açúcar para fins de colheita, por sua vez, provoca periodicamente impactos sobre a biodiversidade da região, com conseqüências deletérias no desempenho dos ecossistemas e na estabilidade da paisagem, além de gerar intensa poluição atmosférica, afetando a saúde dos trabalhadores, dos moradores de áreas rurais e dos centros urbanos mais próximos. Neste sentido, Cruz (2006) afirma, após sistematização de estudos nas áreas de saúde pública, que há na região de Ribeirão Preto um crescimento que varia de $75 \%$ a $100 \%$ das internações por afecções das vias respiratórias registradas no SIH/SUS (Sistema de Informações Hospitalares do SUS) durante o período das queimadas de cana-de-açúcar .

Em termos de impactos ambientais, cumpre ainda destacar que os gases expelidos pela fuligem da cana queimada são o carbônico, os nitrosos (sobretudo o monóxido e o dióxido de nitrogênio) e os sulforosos (como o monóxido e o dióxido de enxofre). Alguns desses gases vão para a atmosfera e podem reagir com a água, gerando ácidos nitrosos e sulforosos que, com grande acumulação, podem gerar chuva ácida, prejudicial ao meio ambiente. Além desses gases, há a formação de vários hidrocarbonetos ou aromáticos contendo benzeno e similares, muito prejudiciais à saúde. (ZAMPERNINI, 1997; ALLEN et al., 2004; ROCHA, FRANCO, 2003; OPPENHEIMER et al., 2004). Apesar de inúmeras denúncias, inclusive do Ministério Público, as queimadas continuam, amparadas na Lei Estadual N. 11.241/2002, cujo prazo para a eliminação da queima é o ano de 2031. No ano de 2007, no entanto, foi firmado um Protocolo entre o governo do Estado de São Paulo e as usinas, pelo qual este prazo seria reduzido para o ano de 2014 para as áreas mecanizáveis e 2017 para as não mecanizáveis. 
Este movimento de capitalização da agricultura na região de Ribeirão Preto gerou profundas transformações não apenas nas formas do espaço regional. Como convém a uma análise que visa integrar o sentido de totalidade da noção de labor, destaca-se ainda o conteúdo da reprodução deste processo modernizador, no âmbito das novas formas de organização e absorção da força de trabalho. A mecanização de frações do processo produtivo, por exemplo, ocasionou a maior captação de força de trabalho temporária, em detrimento da manutenção dos trabalhadores residentes já contratados. Ao serem excluídos do processo produtivo, estes trabalhadores, juntamente com os trabalhadores migrantes provenientes das regiões norte e nordeste do País, formaram um excedente de força de trabalho que vem servindo de maneira funcional ao processo de acumulação, não apenas desta região, mas também de outros espaços afetados pelo agronegócio no Estado.

Sob a perspectiva da análise concreta, os problemas relativos à degradação ambiental estão estreitamente vinculados ao acelerado processo de acumulação de capital registrado nos últimos 50 anos. Conforme nos mostra Altvater (1995) acerca do que chama de pilhagem ambiental, o moderno sistema industrial capitalista depende de recursos naturais numa dimensão desconhecida a qualquer outro sistema social da história da humanidade, liberando emissões tóxicas no ar, nas águas e nos solos. Este sistema necessita, tanto de recursos naturais, como de fontes de energia e matérias-primas quanto de "recipientes", ou seja, locais de despejo, onde os rejeitos gasosos, líquidos e sólidos passam a ser absorvidos ou depositados. Nestes termos, à medida que este sistema se expande, e aceleradamente, o meio ambiente passa a ser visto como um fator restritivo, uma vez que a capacidade de absorção dos ecossistemas globais é pequena.

Isto nos indica que esta pilhagem ambiental compõe um processo mais amplo que não se esgota na denominação de crise ambiental 
- como, por vezes, os ecologistas chegam a afirmar. Revela, a rigor, parte das contradições de uma modalidade histórica de vivência social. Como bem destaca Stahel (1999), trata-se de uma crise da sociedade produtora de valores excedentes, posto que seu modo de reprodução social não é capaz de incorporar em sua lógica a situação de finitude dos recursos ecológicos. Não por outra razão, este autor propõe que a crítica analítica deva dirigir-se aos fundamentos da sociabilidade capitalista, que em sua concepção mecânico-instrumental de tempo (time index), não consegue dar conta da dimensão sistêmica da produção social. Desta feita, os limites da sociedade do valor excedente abrangeria tanto as contradições das relações de trabalho quanto sua incapacidade de interpretação do esgotamento do objeto alvo do trabalho social.

Também seguindo este marco teórico, Harvey (1994), resgatando os conceitos de valor excedente e acumulação de capital, procurou enfatizar que uma das características essenciais do modo de produção capitalista diz respeito à sua necessidade de expansão. Tal necessidade vincula-se estritamente às finalidades de crescimento das taxas de lucro - assegurando, assim, altos níveis de acumulação - e de obtenção de vantagens na concorrência inter-capitais. De acordo com o autor, este expansionismo, responsável então pela dinâmica tecnológica e organizacional do capital, tem-se realizado historicamente, a despeito de suas consequências sociais, políticas, geopolíticas e ecológicas nefastas. Neste mesmo sentido, Foladori (2001) nos afirma que a tendência ao incremento da rotação do capital para o aumento do lucro constitui-se na explicação mais contundente do avanço capitalista sobre territórios e elementos da natureza não mercantilizada. Isto porque, se nas sociedades pré-capitalistas o limite da produção social era a criação de valores de uso, no capitalismo o movimento de acumulação - por via da produção de valores excedentes - é a finalidade última, o que lhe asseguraria, segundo o autor, a ausência de 
limites. Deste modo, a suposta ausência de fronteiras naturais se constitui em um dos pilares da lógica de produção capitalista. E, como bem sugere O'Connor (1991), estas crescentes barreiras naturais de expansão da produção capitalista constituem-se na segunda, contradição essencial do próprio modo de produção. Isto é, as formas sociais de apropriação do trabalho e da natureza revelariam simultaneamente as bases para realização do capital (como relação social), bem como suas contradições essenciais, através da degradação de ambos.

O avanço desta leitura analítica dos processos de degradação ambiental é justamente o de permitir que os processos ecológicos sejam interpretados no âmbito dos processos de produção de valor, através de uma abordagem histórica e concretamente situada, ultrapassando assim, a simples condição de base biofísica dos processos de acumulação. Conforme ressalta Leff (2001, p. 73-74):

se a formação do valor surge como o centro organizador dos processos produtivos do capital, seu meio está conformado pelos processos ecossistêmicos de produção e regeneração de um sistema de recursos que, ao não incorporar trabalho vivo, são carentes de valor. Entretanto, a dotação de recursos, sua capacidade de regeneração e sua produtividade ecológica, os limites para as taxas e os ritmos de exploração dos recursos fixados pela resiliência e a capacidade de carga do meio, condicionam o processo de valorização, de acumulação e reprodução do capital.

No sentido de complexificar a teia de relações que sustenta a agroindústria sucroalcooleira da região de Ribeirão Preto, articularemos os impactos ambientais supracitados aos conflitos entre capital e trabalho que mantêm os níveis de acumulação do setor e asseguram-lhe o caráter de modernidade no escopo da sociedade produtora de valores excedentes. Para tanto, interpretaremos a dinâmica do trabalho temporário na região, assegurando o pressuposto conceitual de que o contexto de uso intensivo 
dos recursos naturais pela moderna agricultura paulista apenas pode ser compreendido, em seu sentido concreto, quando relacionado com a dinâmica das relações de trabalho no campo.

\section{Produção de valor excedente e degradação do trabalho}

Segundo estimativas da Pastoral do Migrante, mais de 200 mil trabalhadores no período da safra da cana, laranja e café no Estado de S. Paulo, são migrantes. Pelo fato de serem temporários, muitas vezes não são computados pelas estatísticas dos órgãos oficiais. Este fato denota a invisibilidade desta mão-de-obra, agravada pelas relações de trabalho baseadas na terceirização. Nos últimos anos, tem havido muitas denúncias de trabalho em condições análogas à de escravo na região de Ribeirão Preto. Geralmente os registros de trabalho escravo são feitos em lugares distantes da região sudeste, nas chamadas áreas de fronteira agrícola, portanto, a variável geográfica é, com muita frequência, vista como um dos determinantes da explicação das relações escravistas. Se, por um lado, tais registros e denúncias são importantes para punir e frear tais práticas, por outro lado, o silêncio ou até mesmo a negação de relações escravistas no centro moderno e dinâmico do agronegócio pode conduzir a possíveis vieses de análise e, pour cause, reforçar a ideologia modernizante que aí se processa.

Além destes registros, há muitos outros relatados pela Pastoral dos Migrantes, durante as visitas cotidianas que são feitas aos alojamentos dos migrantes espalhados pelas fazendas de cana e às pensões, situadas nas chamadas cidades-dormitórios da região. Em 2004, foram visitados 72 alojamentos, e mais de 4 mil pensões localizadas nas cidades dormitórios, que albergam cerca de 62 mil migrantes provenientes dos Estados do Nordeste e Norte dos Estados de Minas Gerais e do Paraná. 
As denúncias e registros de condições análogas àquelas de trabalho escravo se reportam aos trabalhadores migrantes, provenientes de várias partes do país, sobretudo daquelas mais pobres. Este fato sugere uma análise que leve em conta a segmentação da força de trabalho porque, na verdade, a separação entre migrantes e não migrantes entre os trabalhadores de fora e os locais encobre a divisão étnica do trabalho, dado que a maioria dos migrantes é constituída por negros e pardos. Isto não significa afirmar que os locais sejam todos brancos; ao contrário. Muitos deles são descendentes de trabalhadores negros, mestiços de diferentes matizes, provenientes destas mesmas regiões, que para cá vieram e se estabeleceram definitivamente a partir das décadas de 1960 e 1970. As chamadas cidades-dormitório encravadas no meio dos canaviais das usinas tiveram um significativo aumento populacional com a vinda destes migrantes neste período (SILVA, 1999). Não obstante, os critérios de regionalidade paulista e não paulista - são reapropriados pela ideologia étnico/racial que aprofunda as divisões entre os trabalhadores, segmentando-os segundo a procedência geográfica e escamoteando a categoria étnico/racial.

Um outro dado extraído dos registros/denúncias se reporta à superexploração desta força de trabalho, a ponto de extrapolar os limites físicos, ocasionando as mortes nos canaviais. No período de 2004 a 2007, houve 21 mortes, registradas pela Pastoral dos Migrantes, provocadas supostamente pelo excesso de esforço, uma verdadeira overdose do trabalho, denominada birola, pelos trabalhadores. Além das condições alimentares insuficientes - causadas pelos baixos salários, do calor excessivo, do elevado consumo de energia, em virtude de ser um trabalho

\footnotetext{
7 A ocorrência das mortes foi objeto de dez Audiências Públicas, chamadas pela Procuradoria Geral da República, Ministério Público, Ministério Público do Trabalho, ONGs e Comissão dos Direitos Humanos da Assembléia Legislativa do Estado de São Paulo, no final de 2005 e início de 2006. A questão central debatida nessas Audiências foi os direitos humanos do trabalho, além do descumprimento das normas trabalhistas, sobretudo a NR31.
} 
extremamente extenuante -, a imposição da média, ou seja, da quantidade diária de cana cortada, cada vez mais crescente, tem sido o definidor do aumento da produtividade do trabalho, principalmente a partir da década de 1990, quando as máquinas colhedeiras de cana passaram a ser empregadas em números crescentes. Esta imposição atinge não somente os migrantes, como também os trabalhadores locais. Por esta razão, estes capitais necessitam de mão-de-obra jovem, dotada de muita energia física para o desempenho desta atividade. Assim, a rotatividade torna-se muita alta, em virtude da reposição constante da força de trabalho, consumida durante o processo produtivo.

Em síntese, do conjunto de registros/denúncias acima descrito, três foram as questões levantadas pela presente análise: a segmentação da força de trabalho a partir da divisão étnica do trabalho, sem contar a questão de gênero, pois as mulheres foram praticamente alijadas do corte da cana (SILVA, 1999); a imobilização da força de trabalho de migrantes, muitos dos quais sujeitados aos gatos, em virtude das dívidas contraídas e alojados em condições extremamente precárias; a superexploração, responsável pelas mortes durante o processo de trabalho. Vale ainda lembrar que, ademais dos casos relatados, o estudo de Rumin (2004) na região oeste do Estado de S. Paulo constatou a ocorrência da birola e, em outras pesquisas (SILVA, 2004) também houve relatos sobre mortes de parentes, atestadas como enfarte pelos médicos, ocorridas após muitas cãibras durante o corte da cana, geralmente no período da tarde.

Com o intuito de aprofundar as reflexões sobre a definição ou a conceituação deste trabalho e responder aos questionamentos que os dados suscitam, optamos por acrescentar à análise algumas considerações sobre as correntes invisíveis que atam os trabalhadores a estas relações sociais.

A migração temporária aparece como uma estratégia, como uma solução material num duplo sentido: por um lado, o assalariamento permite 
a compra de alimentos, garantindo, assim, um patamar mínimo de sobrevivência; por outro, a saída da terra corresponde à volta, já que o trabalho assalariado é temporário. Cria-se, portanto, um elo de complementaridade bastante estreito entre estas realidades, que, apesar de opostas, se servem mutuamente. Em outros termos, a economia capitalista avançada necessita desta mão-de-obra barata em seu espaço por algum tempo e a economia miserável necessita do parco dinheiro auferido por alguns de seus membros para continuar existindo.

É preciso não esquecer que o migrante parte em busca de melhoria de vida, isto é, de um projeto de ascensão social. O retorno, ou melhor, a representação do retorno é carregada destes valores. Logo, os fracassos, as perdas representariam a ruptura com o ideal da partida, o que pode resultar em sanções negativas por parte do grupo. Esta poderia ser a explicação para as ações daqueles que não retornam, que desaparecem. O desgarramento familiar pode conduzir ao desenraizamento social e cultural, cujo processo de alienação é reforçado pelo uso de bebidas alcoólicas e drogas ${ }^{8}$ que apressam a morte física e social.

Outro ponto que decorre destas reflexões é o referente aos padrões de masculinidade, ou seja, aos papéis que devem ser desempenhados pelos homens. A figura do chefe de família, do provedor, está associada aos padrões patriarcais que atravessam todas as classes sociais. Tais padrões se, por um lado, conferem poder aos homens, legitimando a dominação masculina sobre as mulheres, por outro lado, podem ser considerados como verdadeiros fardos. Deste modo, o homem é identificado como viril, destemido, capaz de enfrentar todos os perigos. Este é mais um dos

8 A Rede Social de Justiça e Direitos Humanos foi a responsável pela coleta de dados sobre o uso de drogas pelos cortadores de cana na região de Ribeirão Preto, onde há, inclusive, uma clínica de tratamento para os usuários Folha de S. Paulo, Ribeirão, 14 de outubro de 2007, p. C10). Andrade (2003) encontrou esta situação na região de Jaú. Na região de São José do Rio Preto, há ocorrências de trabalhadores que recorrem ao uso do crack a fim de aumentar os níveis de produtividade no corte da cana. (Diário da Região, 08 de junho de 2008, p. 2). 
elos destas amarras invisíveis que prendem muitos trabalhadores às redes de trabalho escravo. Não se trata de desconhecimento da realidade a ser vivida. Ao contrário. Trata-se de um verdadeiro enfrentamento, de uma provação para o próprio indivíduo e para o grupo ao qual pertence. É uma espécie de rito de passagem. O sofrimento e a dor são silenciados em virtude da internalização de tais valores e padrões socioculturais.

No que tange ao contrato de trabalho, há dois aspectos a serem considerados. Um deles é a relação jurídica estabelecida entre compradores e vendedores da força de trabalho. Neste momento, os dois agentes são portadores de direitos iguais, legalmente reconhecidos, uma vez que a operação envolve um ato de compra e venda, feito entre indivíduos livres, isto é, nenhuma corrente visível obriga, pelo uso da força física, a assinatura do contrato, aliás, algo também legitimado pelos representantes dos trabalhadores no momento dos acordos coletivos. O outro aspecto, menos visível, porém não menos importante, é a aceitação forçada, involuntária e latente deste contrato jurídico.

Neste momento, vale a pena refletir sobre uma possível escolha de não aceitação do contrato de trabalho por parte dos trabalhadores. No tocante aos migrantes, que já chegam, em sua maioria, endividados, eles não teriam condições financeiras de regressar aos seus lugares de origem, distantes a milhares de quilômetros. Além disso, o regresso sem dinheiro para o sustento da família significa, antes de tudo, a violação das normas de comportamento vigentes no interior do grupo ao qual pertence. Portanto, é difícil afirmar que há liberdade no momento da aceitação do contrato de trabalho. É difícil não pensar na vergonha do provedor fracassado. Inúmeros são os casos de trabalhadores desaparecidos. Não somente aqueles que foram assassinados por capangas em outras regiões, segundo as denúncias de muitos estudiosos e agentes de movimentos sociais, dentre eles a CPT. Dentre os desaparecidos, há que se considerar aqueles que 
fogem e não voltam ao lugar de origem. E mais. Estas fugas também se reportam aos trabalhadores locais, aqueles que são despedidos, que são desempregados em virtude do aumento do emprego de máquinas. Durante as pesquisas em várias cidades-dormitório desta região, foi constatado que, em torno de $30 \%$ das famílias, referem-se às chefias de mulheres. Segundo elas, os homens foram embora. Na realidade, não se trata de partida, mas de fuga. Fuga por medo das sanções sociais negativas.

A verdadeira coação é aquela que o indivíduo exerce sobre si mesmo, segundo as reflexões de Elias (1990). Logo, a imposição das altas taxas de produtividade do trabalho, que extrapolam os limites físicos dos trabalhadores, levando-os, em alguns casos, à morte, é suportada em virtude deste processo de introjeção da autodisciplina que os acompanha durante toda a vida. Do mesmo modo, pode-se interpretar a reposição energética, por meio da distribuição do leite de soja ou até mesmo da aplicação de injeções - as amarelinhas, segundo a definição dos próprios trabalhadores - ou ainda, a aceitação dos kits - soro, farinha e vitaminas para serem ingeridos durante o trabalho - a fim de minorar os efeitos de cãibras, provocadas pela perda excessiva de potássio. Em se tratando dos colhedores de laranja, a fim de evitar a contaminação dos pomares, os trabalhadores são literalmente pulverizados com venenos, antes do início das atividades. Muitos depoimentos foram recolhidos acerca desta prática, normalmente negada pelos proprietários e até mesmo pelos colhedores, em virtude do medo de serem despedidos.

Além das mortes ocorridas nos canaviais, há aquelas não registradas e que ocorrem ao longo de um tempo determinado. Doenças como câncer, provocado pelo uso de veneno, fuligem da cana, além de doenças respiratórias, alérgicas, da coluna, aliadas à quase total impossibilidade de serem tratadas, em razão da inexistência de recursos financeiros para a compra de remédios conduzem à morte física ou social de muitos tra- 
balhadores, cuja depredação de suas forças impede-os de continuar no mercado de trabalho. Por outro lado, o trabalho considerado em sua essência constitui-se em parte integrante do homem, enquanto ser social, segundo a tese lukacsiana. Em outros termos, o trabalho é o definidor da essência humana. Por meio do trabalho, historicamente, o homem modificou a natureza e modificou a si mesmo. Esta modificação se refere ao próprio ser, à interioridade e não somente às condições exteriores, objetivas e materiais. O não-trabalho significa a negatividade desta essência, portanto a negatividade do próprio ser social. Assim, o trabalho não traz apenas a satisfação das necessidades físicas e biológicas, como também sociais e ontológicas. A ausência do trabalho corresponderia à ruptura desta base ontológica do ser social.

A elevação continuada da média induz ao sofrimento, dor, doenças e até mesmo à morte. O uso de drogas - maconha e crack - visa o aumento da capacidade de trabalho durante o corte da cana e também para tolerar o intolerável. As frases, "Não dá para acompanhar o campo de cara limpa, me transformei num bagaço de cana", refletem a crueza e a brutalidade dessas relações de trabalho. A maconha, segundo depoimento de um trabalhador, alivia as dores nos braços, já que, para o corte de 10 toneladas de cana, são necessários quase 10 mil golpes de facão. Quanto ao crack, trata-se de uma droga estimulante, portanto, o seu uso possibilita maiores ganhos de produtividade. Este fato, além de invisível, é proibido, pois, numa sociedade permeada pela violência como a brasileira, o silêncio, muitas vezes, é uma estratégia de sobrevivência. O aumento da taxa de exploração põe em risco não somente a força de trabalho, como também o próprio trabalhador. Desta sorte, a imposição da média, bem como a aceitação pelos trabalhadores, constitui-se num dos elos das correntes invisíveis que os atam a estas relações. No que tange aos casos de reincidentes de trabalho escravo, o retorno à mesma situação ocorre 
em virtude da ausência de alternativas, portanto, de liberdade. O conteúdo latente das duas relações é o mesmo. O elemento mascarador é justamente o conteúdo manifesto, pelo qual há visibilidade nas relações escravistas, em função da imobilização da força de trabalho e da coerção física ou moral. No que concerne aos trabalhadores assalariados e membros do contrato jurídico, estes fatores são camuflados pelas relações livres de compra e venda da força de trabalho.

O leitor, neste momento, poderia indagar-se a respeito das lutas e resistências da sociedade ante os ritmos de degradação do meio ambiente e do trabalho na região. No contexto internacional, alguns trabalhos apontam que a institucionalização das necessidades sociais relativas à garantia dos direitos de cidadania, bem como da pressão social crescente pela preservação de ecossistemas como forma de assegurar condições ambientais de vivência, têm sido a principal alternativa moderna de restrição aos efeitos socialmente indesejados da produção capitalista nas sociedades democráticas (BUTTEL; TAYLOR, 1994). Nestes termos, os debates em torno dos direitos trabalhistas e, mais recentemente, a constituição de metas de políticas ambientais, por exemplo, são algumas das formas de mobilização social mais recorrentes em busca da integridade sócioambiental dos territórios submetidos à acumulação capitalista.

Na região de Ribeirão Preto, a pouca visibilidade social das transformações ambientais, sobretudo no que concerne às águas subterrâneas (invisível ao olhar não-perito) e solos rurais (encobertas pela paisagem da monocultura) têm permitido a desatenção da grande parte da sociedade organizada para a pilhagem ambiental em processo na região. Todavia, no caso do trabalho social, a nitidez dos limites físicos dos trabalhadores, revelados pelas mortes nos canaviais, tem chamado a atenção de distintos setores da sociedade civil e de parte do poder público. A fim de fornecer alguns subsídios sobre as resistências à esgarçadura deste trabalho, opta- 
mos por apresentar alguns excertos dos relatórios das primeiras audiências públicas realizadas com o propósito de enfrentar parte dos dilemas aqui mencionados.

\section{Novos atores e novas formas de resistência}

As primeiras audiências públicas se realizaram no mês de outubro de 2005, na cidade de Ribeirão Preto, a fim de apurar as mortes dos trabalhadores rurais, ocorridas em função do excesso de esforço exigido durante o corte da cana.

A responsabilidade da primeira audiência coube à Relatoria Nacional para os Direitos Humanos à Alimentação Adequada, à Água e à Terra Rural. A referida Relatoria Nacional faz parte do projeto "Relatores Nacionais em Direitos Humanos Econômicos, Sociais e Culturais (DHESC)", coordenado pela Plataforma Brasileira DHESC, com apoio do Programa de Voluntários das Nações Unidas (UNV/PNUD/ONU) e da Procuradoria Federal dos Direitos do Cidadão, do Ministério Público Federal, cujo objetivo primordial é contribuir para que o Brasil adote um padrão de respeito aos direitos humanos, com base na Constituição Federal e nos tratados internacionais de proteção dos Direitos Humanos ratificados pelo país, através da nomeação de especialistas relacionados a direitos específicos (educação, saúde, alimentação, moradia adequada, trabalho e meio ambiente).

A segunda audiência coube à Relatoria Nacional para o Direito Humano ao Trabalho que integra o mesmo projeto da Plataforma DHESC. A essas audiências compareceram representantes dos organismos institucionais do Ministério Público, do Ministério do Trabalho, por meio de delegados regionais, procuradores e promotores; representantes de ONGs e dentre elas, cabe destacar a Pastoral dos Migrantes, responsável pelas denúncias das mortes; pesquisadores e alunos das Universidades Públicas 
(Unesp, Usp, Unicamp e UFSCar); representantes dos Sindicatos de Trabalhadores Rurais, além da FERAESP (Federação dos Trabalhadores Rurais Assalariados do Estado de São Paulo); trabalhadores rurais e a esposa, viúva de um dos mortos; alguns representantes das usinas da região.

A realização das audiências públicas ${ }^{9}$ constitui-se num fato novo no contexto dessas relações de trabalho. Muito embora, tenha havido denúncias de irregularidades em razão do descumprimento da legislação trabalhista, encaminhadas ao Ministério Público, em vários momentos, a chamada para duas audiências pela Procuradoria Geral da República de São Paulo e pela Plataforma DEHSC, ambos organismos situados fora do domínio das grandes empresas, merece uma análise mais detalhada sobre esta realidade. Em nosso entendimento, as audiências públicas representam um marco importante no processo das lutas dos trabalhadores do Estado de São Paulo, cujos desdobramentos ainda estão ocorrendo.

A primeira audiência, presidida pelo Procurador Geral da República de São Paulo, dos Direitos do Cidadão, Dr. Sérgio Gardenghi Suyama, contou com a colaboração do Dr. Flávio Luiz Schieck Valente, relator nacional para os Direitos Humanos à Alimentação, Água e Terra Rural, registrou a presença de 220 pessoas e teve duração de quase 8 horas ininterruptas. Antes, porém, foram realizadas uma reunião com representantes da Pastoral dos Migrantes sediada na cidade de Guariba, bem como dos Sindicatos de Trabalhadores Rurais e uma visita aos canaviais e a um alojamento da Usina Bonfim, cuja situação, descrita numa parte do relatório, é a seguinte:

9 A audiência pública tem como objetivo obter subsídios e informações junto à sociedade civil para elaboração de um plano específico para atuar em uma determinada área. O referido plano estabelece as metas prioritárias em cada uma dessas áreas de atuação que possibilita, dentro do planejamento estratégico, definir ações institucionais para alcançar os objetivos traçados. $\mathrm{E}$ sempre será aberta ao público em geral. No Brasil, tem previsão na Lei no 9.784/1999, como mecanismo de instrução do processo administrativo federal, visando ao desempenho da função administrativa pelos entes da Administração Pública Direta e Indireta, dos três Poderes da União, a saber: Poder Executivo, Poder Legislativo e Poder Judiciário. O Ministério Público representa na audiência pública, indispensável instrumento para realização da missão institucional. 
Os trabalhadores saem de suas casas e/ou dos alojamentos entre as 5 e 6 horas da manhã, chegando aos canaviais um pouco antes das sete. O horário do almoço se dá em torno das 11 horas da manhã, não havendo tempo definido para a parada. Os trabalhadores locais trazem a comida de casa, quando saem cedo. Os trabalhadores alojados (migrantes) recebem a comida da empresa quando saem para trabalhar cedo. Alguns comem o alimento aos poucos, outros comem tudo de uma só vez. Os trabalhadores acham que a quantidade da alimentação oferecida pela empresa é suficiente, mas a qualidade é inadequada, sem tempero e sabor. Muitas vezes a comida azeda, especialmente se está muito quente.

Vários trabalhadores relatam que cortam entre 15 a 20 toneladas de cana por dia. Os migrantes, em média, são mais jovens que os trabalhadores locais. Vários dos trabalhadores migrantes têm em torno de 20 anos.

Durante toda a visita, os funcionários da Usina se desdobraram para manter-se próximo do Relator e dos representantes da DRT e do MP, tentando impedir que os trabalhadores se sentissem livres para manifestar sua opinião. Somente em breve momentos houve a oportunidade de conversar mais francamente com os trabalhadores.

As condições do alojamento se aproximam a de uma prisão. Em cada quarto existem 3 ou 4 camas. Os cômodos não têm janelas e as portas se abrem todas para um corredor interno. A área onde é feita a lavagem dos utensílios de trabalho é a mesma onde se lavam as marmitas e onde se obtém água para consumo individual. A presença de funcionários da empresa, durante todo o tempo em que estivemos no alojamento foi intensa, tentando impedir o acesso livre aos trabalhadores.

No Relatório da segunda Audiência Pública, presidida pela Dra. Cândida da Costa a situação encontrada é assim descrita:

Os trabalhadores entrevistados no alojamento Jibóia (Usina do grupo Cosan em Rio das Pedras) são oriundos do estado de Minas Gerais, especificamente dos municípios do Vale do Jequitinhonha, destacando-se os municípios de Araí, Araçuaí, Novo Cruzeiro, Salinas. A idade varia entre 20 e 50 anos, não havendo, portanto, um perfil etário determinado. No tocante 
ao perfil racial, a identificação é visível: o índice de negros e pardos é absolutamente maior que o de qualquer outro segmento racial; com formação educacional incompleta ou inexistente, uma vez que foram identificados trabalhadores analfabetos ou mesmo com grau de alfabetização deficiente, o que não configura também um nível educacional uniforme.

O turno de trabalho começa diariamente às 05 h30 minutos, sem hora prevista para terminar. Durante a jornada de trabalho, os trabalhadores são obrigados a cortar a cana o tempo inteiro, sem direito a pausa para descanso, parando para almoçar e sendo obrigados pelo chefe da turma a retomar o corte imediatamente, ação legalmente proibida, uma vez que a legislação trabalhista vigente determina como intervalo mínimo para almoço, o período de uma hora e máximo de duas, constituindo-se a obrigatoriedade de retomada do trabalho imediatamente pelo trabalhador, numa violação do dispositivo legal em vigor. Chegam a cortar até 600 metros de cana por dia, o que seria equivalente a $R \$ 30,00$ diários. A empresa fornece as ferramentas, botas e luvas. As roupas utilizadas no corte da cana são compradas por conta própria, não há o fornecimento de máscaras nem de óculos, o que obriga os trabalhadores a inalar a fuligem da cana queimada, e também a não proteger os olhos do contato com a fuligem e as partículas de cana. Embora o horário determinado para término da jornada seja às 15h50', sempre se estende sem hora fixa para terminar, além de os trabalhadores serem obrigados a realizar outras atividades laborativas como o recolhimento de bituca (pedaço) de cana-de-açúcar, após encerrarem o corte da cana, o que estende a jornada de trabalho, visto que são mantidos no local de trabalho, mas não recebem acréscimo nos salários por tais atividades.

O contrato é por produção, o que não configura uma remuneração fixa, baseada em um piso salarial uniforme, deixando o pagamento à mercê do ritmo de produção individual dos trabalhadores. O que resulta num esforço além da capacidade física dos trabalhadores, obrigando-os a entrar num clima de competição, visando destacar quem realiza a maior produção. A existência de tal procedimento resulta na violação do artigo $7^{\circ}$., do Pacto Internacional dos Direitos 
Econômicos, Sociais e Culturais, que dispõe o direito a condições justas e favoráveis de trabalho, bem como de uma remuneração igual para um trabalho de igual valor.

A alimentação é fornecida pela usina, que efetua o desconto de $R \$$ 95,00 diretamente do pagamento dos trabalhadores. Durante a jornada de trabalho, a comida fica armazenada na marmita dentro da sacola na qual os trabalhadores transportam as ferramentas e a alimentação, fica sob o sol no decorrer do dia. O que resulta na deterioração da comida, obrigando os trabalhadores a jogá-la fora, ficando durante o restante do dia sem alimentar-se, ou quando recebem lanche pela usina, usando-o como refeição principal. Entretanto, conforme o artigo 200, incisos V e VII, da CLT, bem como da NR 3110, artigos 31.23.4.2 e 31.23.4.3, é obrigatória a existência de abrigos para proteção dos trabalhadores das intempéries, e armazenamento da comida ${ }^{11}$.

A usina fornece água para os trabalhadores. Entretanto, a água não é submetida aos tratamentos convencionais de filtração e/ou fervura, sendo retirada das torneiras dos banheiros localizados próximo aos dormitórios, ou de um lavatório próximo ao refeitório onde os trabalhadores lavam seus copos, pratos e talheres, no qual foram encontrados insetos mortos no momento da entrevista dos trabalhadores.

Por diversas vezes os trabalhadores pediram para ir embora, mas recebem a resposta de que só irão embora quando acabar a safra da cana, pois dependem que a empresa providencie o ônibus para voltarem a seus estados de origem. A empresa ameaça os trabalhadores de não recontratá-los na próxima safra, se procurarem o sindicato ou algum órgão público de defesa de direitos de trabalhadores. Além de ameaçarem a inclusão dos nomes dos trabalhadores que

10 Norma Regulamentadora de Segurança e Saúde no Trabalho na Agricultura, Pecuária Silvicultura, Exploração Florestal e Aqüicultura - NR 31, Portaria no. 86, de 03/03/05 - Diário Oficial da União de 04/03/05.

11 NR 31: 31.23.4.2 - Em todo estabelecimento rural deve haver local ou recipiente para a guarda e conservação de refeições, em condições higiênicas, independentemente do número de trabalhadores.

31.23.4.3 - Nas frentes de trabalho devem ser disponibilizados abrigos, fixos ou móveis, que protejam os trabalhadores contra as intempéries, durante as refeições. 
cooperarem com as investigações feitas pelo Ministério Público do Trabalho, Ministério do Trabalho e Emprego e com as denúncias nos sindicatos em uma lista que será entregue também nas outras usinas para evitar que os trabalhadores que denunciaram as violações de direitos efetuadas pela empresa sejam contratados na próxima safra ${ }^{12}$.

O conteúdo dos dois relatórios contribui para o embasamento de vários caminhos das reflexões teóricas. No que se refere às discussões precedentes, podem-se destacar ao menos cinco desdobramentos conceituais de grande relevância para o debate sobre a exploração do trabalho social na agricultura, quais sejam:

- as consequências físicas da intensidade da exploração da força de trabaIho dos migrantes no curso da Revolução Verde no país;

- a supressão, nos termos empregados por Arendt (2005), das esferas da ação (transcendência de sua condição de trabalhador em direção à política em sentido amplo) e do trabalho (exercício de dominação do saber social sobre natureza, baseado em atividades teleologicamente orientadas) em benefício da prevalência da dimensão do labor no cotidiano do canavial, com a garantia única de sua sobrevivência orgânica. - a permanência, por conseguinte, do trabalho temporário como expressão não apenas econômica, mas também política do desenraizamento do trabalho social;

- a transitoriedade do trabalho como forma de aumentar o sofrimento. Suporta-se o insuportável porque se imagina que é transitório, por que se tem a esperança do não regresso na próxima safra, se tudo correr bem, se chover nas regiões de origem, se conseguir-se um emprego melhor, e, assim por diante;

12 Relatoria Nacional para o Direito Humano ao Trabalho. Relatório da Missão realizada no período de 24 a 27 de outubro de 2005 na região de Ribeirão Preto/SP para a apuração de violações de Direitos Humanos de trabalhadores (as) canavieiros (as), 2005, p. 6-22. 
- o autoritarismo expresso nas diversas modalidades de violências empreendidas contra os trabalhadores migrantes. Assim como destacava Weber a propósito da participação dos trabalhadores poloneses livres na economia Junker-prussiana, "morar sob um teto estranho é o princípio da dependência econômica e das condições de dominação" (WEBER, 1990, p. 236). As relações estabelecidas nos alojamentos destes migrantes são sintomáticas a este respeito ${ }^{13}$.

Sem embargo, alguns pontos ainda cortam os desdobramentos supra, de modo transversal e merecem atenção. A presença dos representantes do Ministério Público, por intermédio dos promotores ${ }^{14}$, procuradores e de outros organismos institucionais (Ministério do Trabalho), além das ONGs (Pastoral dos Migrantes, Plataforma DHSC), dos representantes das Universidades e dos trabalhadores, sugere que houve um alargamento do campo das contradições entre capital e trabalho. Neste embate, esses atores não só se fazem presentes, como também possuem poderes, embora diferenciados, capazes de redirecionar os antagonismos, por meio de pressões em torno da obediência às normas legais, impondo, portanto, limites à voracidade destes capitais e exigindo do Estado a regulação das relações de trabalho, indo de encontro à desregulação e fexibilização impostas pelo capitalismo mundializado. Defende-se a idéia de que o Estado não é constituído por um bloco monolítico. O mesmo ocorre com as instâncias jurídicas. No que tange ao Ministério Público no Estado de São Paulo, assiste-se, nos últimos anos, sobretudo a partir da Constituição de 1988, a várias ações visando a justiça social e o cumprimento dos direitos humanos universais.

13 Neste sentido, nunca é demais destacar que, em Weber a dominação não é um ato isolado de poder. Além de envolver a legitimidade, a dominação também se estende no tempo, pressupõe continuidade. Ao suporem a transitoriedade desta forma de trabalho, estes migrantes tornam-se decisivamente atrelados à continuidade característica dos processos dominação.

14 Uma importante discussão sobre o papel do MP (Ministério Público) no Brasil, tradicionalmente conhecido como o órgão de proteção aos fracos, o guardião da sociedade, sobretudo a partir dos anos de 1980 e 1990, encontra-se em (SILVA, 2001, p. 127-144). 
Assim, as conclusões descritas no relatório da segunda audiência pública apontam para as fricções entre os organismos estatais, em torno da questão dos direitos humanos do trabalho e também para possíveis ações, tais como sugere o trecho abaixo:

Dispomos, portanto, de um conjunto de evidências que permitem relacionar a morte dos trabalhadores direta e indiretamente à exaustão no trabalho. Vale lembrar que o Japão passou 10 anos para reconhecer a existência da morte súbita no trabalho, ocasionado por sobrecarga de trabalho (karoshi), o qual é descrito na literatura sócio-médica como um quadro clínico extremo (ligado ao estresse ocupacional) com morte súbita por patologia coronária isquêmica ou cérebro vascular. Não é de fácil detecção, vez que estudos publicados mostram que métodos convencionais de check up são insuficientes para detectar precocemente sinais de efeitos adversos à saúde por excesso de horas trabalhadas e conclui que o aparelho cardiovascular de executivos fica "sobrecarregado" com o excesso de horas trabalhadas. Sua sintomatologia terminal apresenta os ataques cardíacos e os acidentes vasculares cerebrais (AVCs) acometendo mais, aqueles que trabalham mais de 3000 horas/ano. Portanto, a morte súbita é um acometimento fatal por sobre-esforço, sendo considerada uma doença relacionada ao trabalho, freqüentemente, associada a longos períodos de horas trabalhadas, não podendo ser descartada na situação ora em análise.

O trabalho no cumprimento de sua função social tem como natureza proporcionar a todo ser uma forma de vida digna baseada na emancipação da pessoa humana, sendo, portanto, um dos princípios dos direitos humanos. A forma como é utilizada a mão-de-obra pela empresas monocultoras no interior do estado de São Paulo condiciona os trabalhadores à alienação pelo trabalho, dependência e exploração, convertendo o que seria um direito humano obrigatoriamente garantido pelo Estado, num esforço penoso, aprisionador dos seres humanos. Cabe, portanto, ao Estado brasileiro, compreendido nas suas esferas municipais, estaduais e federal, zelar pelo respeito ao trabalho como um direito humano, buscando-lhe meios de efetividade, visando garantir que a sua implementação propor- 
cione aos cidadãos trabalhadores meios capazes de prover a sua vida e de seu familiares, de forma digna.

No dia 14 de dezembro ocorreu, a terceira audiência pública para tratar das questões das mortes dos trabalhadores, chamada pela Comissão de Agricultura e Pecuária da Assembleia Legislativa do Estado de São Paulo. Em novembro de 2007, outra audiência pública foi realizada em Ribeirão Preto, também chamada por deputados da Assembleia Legislativa. Este fato demonstra a maior amplitude da participação dos atores envolvidos, incluindo deputados estaduais, cuja proposta foi a abertura de uma CPI para a apuração dessas mortes.

No que concerne à participação das instituições, há várias fricções, que transparecem em alguns pontos dos relatórios acima. Por outro lado, na última audiência, esse fato se tornou mais evidente, sobretudo por intermédio da Procuradoria Geral do Trabalho da $15^{\text {a }}$ Região, representado pelo Dr. Ricardo Garcia, cujo depoimento corroborou as críticas já feitas ao Ministério do Trabalho, relativamente à inoperância quanto à fiscalização das relações de trabalho nesta região. Aliás, tais críticas também foram feitas pelos representantes dos trabalhadores durante as audiências anteriores. Além do Ministério do Trabalho, a Vigilância Sanitária em vários municípios e o INSS (Instituto Nacional de Seguridade Social) também sofreram críticas por parte dos procuradores e promotores. Ficou claro que, no tocante às ações destes organismos estatais, há omissão, descaso e conivência com os interesses das empresas. Ressaltamos, portanto a importância dos representantes do Ministério Público no sentido de defender os direitos dos trabalhadores, estabelecendo frentes de luta contra os interesses das empresas e também desses organismos estatais.

Muito embora as audiências públicas sejam institucionais, elas existem a partir dos reclamos da sociedade. Segundo seus propósitos, de defesa dos oprimidos, no caso, os trabalhadores rurais do estado de São Pau- 
lo, houve no decorrer destes três últimos anos, a produção de várias ações instituintes, cujos desdobramentos estão encaminhando para a regulamentação de novas relações não somente no tocante à esfera do trabalho, como também na esfera reprodutiva. Portanto, no que se refere à situação social, o poder público, representado pelos Promotores e Procuradores do Trabalho, têm procurado não somente "dar respostas"- ou nas palavras de um procurador "apagar incêndios"-, aos reclamos, como também produzir práticas conjuntas com os representantes da sociedade civil. Tais práticas são o resultado das diversas forças sociais envolvidas. Reiteramos que o campo atual dessas lutas não se reporta à existência de dois pólos contrários: de um lado, os trabalhadores, e de outro, os empresários. Outros atores se fazem presentes, ampliando assim, este campo. Além da realidade descrita acima, nos limites deste texto, acrescentaremos mais algumas evidências empíricas, a fim de aprofundar nossas reflexões.

Nos últimos três anos (2005-2008), a PRT15 (Procuradoria do Trabalho da 15ạ. Região do Estado de São Paulo), tem desenvolvido ações conjuntas com o Fórum da Cidadania, cuja iniciativa é de um vereador de Piracicaba - O. Storel - e reúne 28 cidades com sede em Piracicaba, envolvendo pesquisadores, políticos locais, representantes dos trabalhadores e também agentes de outros órgãos públicos como a Vigilância Sanitária, além do Procurador da PRT15. Resumidamente, as ações desta procuradoria com desdobramentos positivos foram as seguintes:

- aumento das fiscalizações no eito, visando ao cumprimento da NR31: exigências do uso de EPIs; instalação nos locais de trabalho de barracas sanitárias; toldos para proteger os trabalhadores no horário de almoço; exigência de parada de uma hora durante a jornada; distribuição de água potável e fresca aos trabalhadores; verificação do registro em carteira; segurança dos transportes etc; 
- foram enviadas 208 notificações recomendatórias às usinas acerca das questões ambientais (queimadas) e da terceirização da mão-de-obra;

- foram abertos mais de 300 inquéritos desde 2006 sobre as irregularidades trabalhistas e ambientais encontradas; foram abertas mais de 30 ações civis públicas contra as empresas do setor sucroalcooleiro nos municípios desta jurisdição;

- fiscalização das moradias dos migrantes, juntamente com a Vigilância Sanitária, visando à saúde dos trabalhadores. Estando a questão das moradias relacionada à saúde pública - portanto, além da esfera do trabalho propriamente dita - uma das formas utilizadas pelas usinas para se evadirem das responsabilidades trabalhistas e sociais tem sido a de intimidar os trabalhadores. Assim, no momento das fiscalizações das moradias, eles são orientados para afirmar que vieram por conta própria, e, em alguns casos, negam informações sobre os empreiteiros e empregadores;

- ação do TST (Tribunal Superior do Trabalho) no sentido de gerar uma lei que passe a regular as moradias, levando-se em conta a saúde pública, higiene e condições adequadas para os trabalhadores;

- quanto ao transporte até os locais de trabalho, foi feita uma minuta, visando a produção de uma lei que proíba a circulação de ônibus com tempo de uso acima de dez anos;

- recentemente o juiz de Capivari, Marcos Menezes Barberini, proferiu uma sentença contra a Usina São José, afirmando que a terceirização da mão-de-obra prejudicava o meio ambiente. Este fato se constitui como inédito, em razão de aliar as questões do trabalho às do meio ambiente.

No entanto, as práticas visando ao cumprimento da NR31 e à produção de outras leis reguladoras para o cumprimento dos direitos trabaIhistas e humanos esbarram nas seguintes travas impostas pelos usineiros e também pela representação sindical, a saber: 
- a existência de lobbies dos empresários fez com que fosse vetado pelo atual Governador do Estado o projeto de lei relativo ao selo do setor sucroalcooleiro sobre o cumprimento das normas trabalhistas;

- no que diz respeito ao fim do trabalho por produção, responsável pelo aumento abusivo da intensificação da exploração, as barreiras advêm dos empresários e também dos representantes sindicais, especialmente da FERAESP (Federação dos Empregados Rurais Assalariados do Estado de São Paulo). Em virtude da independência funcional, alguns procuradores do trabalho também são favoráveis a essa forma de trabalho, diferentemente do procurador da PRT15. Esta situação faz com que o campo dos conflitos aumente, sem contar que, orientados pelos sindicalistas, muitos trabalhadores aderem a estas posições, na crença ilusória de que o trabalho por produção lhes rende maiores salários;

- após as audiências públicas, a FERAESP se tem posicionado contrária à ação dos promotores no tocante às fiscalizações ${ }^{15}$. Sua prática tem sido a de negligenciar tais ações. Em 2006, foi firmado um Protocolo entre ÚNICA (União da Indústria da Cana-de-açúcar) e FERAESP, cujo conteúdo não fora até então divulgado ${ }^{16}$.

- ainda que as usinas da região tenham-se comprometido a terminar com o fim da terceirização, esta prática é muito presente entre os fornecedores de cana.

Este conjunto de práticas pode ser interpretado à luz dos ensinamentos de Thompson (1987), a propósito da Lei Negra que vigeu na In-

15 Nem todos os sindicatos desta federação estão de acordo com tais posicionamentos. Uma das exceções é o Sindicato de Cosmópolis, que tem defendido novas formas de medição da cana para evitar que os cortadores sejam lesados pelas usinas. Entretanto, tais medidas não são acatadas pelos demais sindicatos, o que comprova a existência de outros conflitos de interesses existentes.

16 A menção a este protocolo consta de uma exposição feita pelo presidente da ÚNICA, Marcos S. Jank, na cidade de Ribeirão Preto em 10 de abril de 2008, no I Workshop do Observatório do setor sucroalcooleiro, intitulada, A Única e os desafios globais da cana-de-açúcar. 
glaterra durante um século (1723-1823), cuja finalidade era impedir o uso comum das florestas pelos camponeses e a transformação delas em propriedade privada. Contrariando uma interpretação instrumentalista, advinda do marxismo-estruturalista, segundo a qual a lei está a serviço das classes dominantes, ele afirma: "A lei considerada como instituição (os tribunais, com seu teatro e procedimento classistas) ou pessoas (os juízes, os advogados, os Juízes de Paz), pode ser muito facilmente assimilada à lei da classe dominante. Mas nem tudo que está vinculado a "a lei" subsume-se a essas instituições" (p. 350-351).

As ações descritas acima visam ao questionamento do poder da classe dos empresários, por meio da criação de um novo campo de lutas do qual participam atores advindos das instituições e também da sociedade civil. Este novo campo de lutas, por sua vez, revela o caráter multifacetado do Estado, que não se restringe ao papel de mantenedor dos interesses das classes dominantes (como um olhar amparado na divisão estrutural althusseriana poderia supor). Os conflitos entre esferas burocráticas distintas (tais como os ocorridos nos últimos anos entre instâncias do Ministério do Meio Ambiente e do Ministério da Agricultura), bem como a presença do Ministério Público na denúncia e/ou mediação de antagonismos sustentados pelas próprias forças governamentais, sugerem a necessidade de se problematizar o Estado em termos de campo de relações, onde instituições, classes e grupos burocráticos competem por condições de hegemonia, produzindo tensões decisivas para as conjunturas sociais de dominação material e simbólica.

No espectro da sociedade civil, cabe ainda mencionar o papel ambíguo das Universidades nas disputas pela argumentação legítima em torno das relações que sustentam o agronegócio. De um lado, vários trabalhos acadêmicos, principalmente das áreas da engenharia, bioquímica e economia, oriundos, sobretudo, de universidades públicas paulistas, demons- 
tram a sustentabilidade da produção de cana-de-açúcar ${ }^{17}$. No que tange à temática ambiental, a sustentabilidade preconizada fundamenta-se, no mais das vezes, em uma argumentação bastante particular sobre dados técnicos. Em um esforço positivista de atribuir o núcleo do argumento aos próprios dados, parte destes estudos é licenciada diante aspectos históricos relacionados com a moderna pilhagem ambiental problematizada na primeira seção deste artigo. Com efeito, esta construção discursiva da sustentabilidade, ao fragmentar trabalho e natureza, aproxima os agentes do agronegócio sucroalcooleiro ao Junker prussiano abordado por Weber, precisamente no que se refere ao interesse em não adequar-se às novas conjunturas históricas. Isto é, como conduta de classe, estes agentes optam por subsumir à sua lógica as novas demandas sociais relativas à dignidade do trabalho e à preservação ambiental.

Por fim, no que tange especificamente às ciências humanas, particularmente aquelas voltadas para as pesquisas rurais, os problemas de pesquisa nos últimos anos no Estado de São Paulo, pouco se reportam aos trabalhadores rurais assalariados. Tais temas foram silenciados por parte dos pesquisadores dessas áreas ${ }^{18}$. A despeito do recente interesse da Aca-

17 Vide a respeito Macedo (2005). Trata-se de uma coletânea, editada pela ÚNICA (União da Indústria da cana-de-açúcar) com a participação de 12 investigadores, pertencentes às universidades públicas paulistas, além de federais e privadas de outros estados. Apesar do titulo da obra se referir à sustentabilidade, constata-se que, em nenhum dos artigos a problemática da exploração dos trabalhadores é discutida, exceto as referências sobre o mercado de trabalho, baseadas nas estatísticas da RAIS, cuja metodologia não abarca os temporários e os que são contratados sem registro formal de trabalho, como os contratados por empreiteiros, denominados "gatos". Recente publicação da Revista da FAPESP (Fundação de Amparo à Pesquisa do estado de São Paulo) revela o quadro das pesquisas realizadas em diferentes áreas do conhecimento sobre a cana, tais como, a genética da cana, a fim de determinar o maior número de variedades possíveis, capazes de aumentar os níveis de produtividade e também melhores condições de plantio da cana em diversos tipos de clima e solo. (Revista Pesquisa Fapesp, n. 122, abril de 2006, p. 62-70).

18 Os temas de pesquisa voltados aos chamados bóias-frias do Estado de São Paulo chamaram a atenção dos pesquisadores, sobretudo nos anos de 1970 e 1980. A partir dos acontecimentos das greves de 1984 e 1985 que resultaram no incremento da mecanização e na luta pela reforma agrária, os problemas de pesquisa se voltaram para os assentamentos rurais, enquanto 
demia pelas chamadas "novas" ocupações rurais, vários processos sociais envolvidos na composição do trabalho temporário permanecem requerendo esforços interpretativos, fato que as informações que apresentamos no artigo deixam mais do que nítido.

\section{Á guisa de conclusão: a degradação dos modos de vida}

Para o viajante que percorre as rodovias paulistas após a cidade de Campinas, indo em qualquer direção, a impressão que terá é que estará no meio de um gigantesco canavial. A história objetivada dessa região caracterizada pelas marcas das antigas fazendas de café, das moradias dos colonos e sitiantes, do multicolorido de plantações de milho, algodão, amendoim, feijão, além de pastagens, das estradas vicinais, das reservas de matas, de pequenos córregos - está em vias de desaparecimento, cedendo lugar ao monocromático dos canaviais, exceto as áreas ocupadas pelos laranjais. Durante os meses de abril a novembro, até mesmo o firmamento aparece enegrecido pelas gigantescas nuvens de fumaça advindas das queimadas da cana, prática predatória ao meio ambiente e à saúde das populações rurais e urbanas que aí vivem. Segundo recente reportagem, os focos de queimada aumentam em mais de 1000\% durante a safra na região de Ribeirão Preto.

As mortes nos canaviais paulistas, somadas à imobilização e coerção física ou moral, revelariam tragédias individuais, se pensadas em suas individualidades. Da mesma forma, a destruição ambiental promovida

os dos assalariados, particularmente dos trabalhadores migrantes, despertaram o interesse de poucos pesquisadores, algo que está, no momento atual, sendo revertido, após as denúncias das mortes nos canaviais, bem como o aumento da exploração. Esta realidade já foi objeto de debate recente (SILVA, 2005) e de discussão da primeira autora deste artigo nos encontros da Rede Rural. Em razão desta discussão, o próximo encontro da Rede, que será realizado em Campina Grande no mês de setembro, contará com uma mesa cuja temática será em torno dos efeitos do chamado agronegócio sobre as relações de trabalho. 
pela monocultura canavieira revelaria prejuízos ambientais, se pensada na simples transformação do território. Contudo, o que confere sentido concreto a estes fenômenos é justamente o modelo de desenvolvimento da agricultura capitalista no país, cujo autodenominado agronegócio é sua forma mais acabada. Conforme destacado na introdução deste trabalho, ainda que esta forma do agronegócio revele características da economia Junker, suas singularidades residem justamente em sua intensidade avassaladora - destruindo, em sentido strictum, recursos naturais e força de trabalho - e, em seu momento histórico, século XXI, era da modernidade e da reflexividade, tempos de garantias cidadãs, dos direitos humanos e sociais, do direito ao trabalho e do que alguns teóricos também vêm chamando de cidadania ecológica (DOBSON, 2003).

Cumpre ainda destacar que a associação deste processo de acumulação no rural paulista, com as características autoritária da economia Junker prussiana não revela um evento fora de seu tempo ou mesmo fora da ordem capitalista. Com efeito, esses processos de esgarçamento do trabalho social e do ambiente natural são intrínsecos à ordem capitalista. Não são, portanto, resquícios de relações arcaicas, resíduos de práticas autoritárias que escapariam do atual nível de racionalização das práticas capitalistas. Ao contrario disso, o capital, como relação social complexa que é, segue desenvolvendo essas modalidades de emprego do trabalho social e da natureza como parte indissociável de seu moderno processo de valorização que articula tecnologias agronômicas de precisão com níveis extremos de degradação sócio-ambiental. É justamente neste sentido que, do ponto de vista analítico, este contexto se revela concretamente como parte da unidade do diverso que compõe o modo capitalista de produção.

Em estudo sobre os campos nazistas de concentração, Pollak (2000) sugere que experiências extremas são reveladoras de elementos de identidade social, de formas de pertencimento e de condições de existência, 
mesmo ante o limite físico e psicológico. Sem embargo, a experiência social do trajeto dos trabalhadores migrantes para o corte da cana em São Paulo, a coerção no trabalho e a possibilidade da morte no canavial - agora repleta de significados, não mais ocorrência eventual - compõem um indiscutível cenário de degradação do trabalho social, cuja situação extrema não impede que, mesmo o silêncio de alguns destes trabalhadores, decorrente dos vários níveis de coerção, denuncie um intenso processo de gestão da identidade, agora ainda mais violentada. Nestas circunstâncias, a reinvenção moderna de exploração do trabalho no agronegócio e a pilhagem ambiental por este promovida compõem um quadro mais amplo de degradação dos modos de vida. Ou seja, levando ao limite crítico as experiências sociais a partir do trabalho e gerando níveis progressivos de exaustão dos recursos naturais, esse modelo de agricultura revela a degradação de suas próprias condições de existência. Revela seus próprios limites por meio da destruição dos trabalhadores e da natureza.

A realização das Audiências Públicas suscita uma possibilidade histórica de os grupos sociais oprimidos fazerem política, incluindo outros atores sociais, alargando, assim, o campo dos conflitos e das contradições. Entretanto, é necessário inaugurar uma nova linguagem que rompa com paradigmas estruturais da ideologia do desenvolvimento, que se arrastam no discurso político desde a década de 1950, ecoando no imaginário social oficial. A realização das audiências não pode ser compreendida somente como meio para "limpar" a imagem do Estado mais desenvolvido da nação, como transparece em muitos depoimentos, sobretudo de representantes de partidos políticos, porém como forma de escovar a contrapelo a história do trabalho desta agricultura, cuja pujança existia e ainda existe, graças à intensa exploração da força de trabalho, sem contar o processo de expropriação, historicamente iniciado com o extermínio das populações indígenas, do trabalho de escravos na agricultura cafeeira, 
na exploração de trabalhadores nacionais e colonos imigrantes e, agora, dos migrantes de outras regiões do próprio país.

\title{
The degradation of labor and nature in the context of the sugarcane monoculture in São Paulo, Brazil
}

\begin{abstract}
This paper discusses the socio-environmental dynamics of the modern sugarcane farming. The article develops a concrete analysis of the agribusiness phenomenon, rescuing the significant relationships that give it concrete meaning $\square$ i.e., that give it a comprehensive position within the unity of the diverse. To this end, the paper examines the dimensions involved in the exploitation of social labor and natural resources within this phenomenon $\square$ emphasizing the region of Ribeirão Preto, in the interior of São Paulo state. The study concludes that: a) the authoritarian relations that constitute the agribusiness phenomenon are in line with those described by M. Weber in his interpretation of the Junker capitalism in Germany; and b) it is necessary to articulate the social and environmental spheres in the analysis of the accumulation processes in the agricultural field, revealing the material and symbolic dimensions that support the conservative modernization represented by the agribusiness in Brazil.
\end{abstract}

Keywords: Rural labor. Agriculture and environment. Labor and environment.

\section{Referências}

ALLEN, A. G. Et al. Influence of sugar cane burning on aerosol soluble ion composition in Southeastern Brazil. Atmospheric Environment. V. 38, p. 50255038, 2004.

ALTVATER, E. O preço da riqueza. São Paulo: Unesp, 1995.

ANDRADE, A. F. Cana e crack: Sintoma ou problema? Um estudo sobre os trabaIhadores no corte de cana e consumo do crack. Dissertação de Mestrado. PPG/ Psicologia Social/PUC/SP, 2003. 
ANDRADE, J.M.F; DINIZ, K.M. Impactos ambientais da agroindústria da canade-açúcar: subsídios para a gestão. Monografia de especialização em Gestão Ambiental. Esalq-USP: Piracicaba, 2007.

ARENDT, H. A condição humana. $10^{\text {a }}$ edição. Rio de Janeiro: Forense Universitária, 2005.

BASTOS FILHO, G.S. Contabilizando a erosão do solo: um ajuste ambiental para o produto bruto agropecuário paulista. Piracicaba: ESALQ, 1995.

BUTTEL, F.; TAYLOR, P. Environmental sociology and global environmental change: a critical assessment. In: REDCLIFT, M.; BENTON, T. (Eds.). Social theory and the global environment. Routledge London and New York, 1994.

CBH-PARDO. Plano de Bacia da Unidade de Gerenciamento de Recursos Hídricos do Rio Pardo. Relatório Final. Comitê de Bacia Hidrográfica do Pardo Realização: CPTI - Cooperativa de Serviços e Pesquisas Tecnológicas e Industriais; IPT - Instituto de Pesquisas Tecnológicas do Estado de São Paulo, 2003.

CEPAL. Globalização e desenvolvimento. Brasília: Comisón Económica para América Latina y El Caribe, 2002.

COSTA, L.M.; MATOS, A.T. Impactos da erosão do solo em recursos hídricos. In: SILVA, Demétrio D.; PRUSKI, Fernando F. (Eds.). Recursos hídricos e desenvolvimento sustentável da agricultura. Brasília: MMA, 1997.

CRUZ, A.P.F.N. A tutela penal das queimadas: o problema da cana-de-açúcar no nordeste paulista. Revista Justitia - Publicada pela Procuradoria-Geral de Justiça. Ministério público de São Paulo, 2006.

DOBSON, A. Citizenship and the environment. Oxford: Blackwell Publisher/ Cambridge, 2003.

ELIAS, N. O processo civilizacional. 2. v. Lisboa: Dom Quixote, 1990.

FIBGE. Indicadores de desenvolvimento sustentável: Brasil 2002. Diretoria de Geociências - Rio de Janeiro: Fundação Instituto Brasileiro de Geografia e Estatística, 2002.

FOLADORI, G. Limites do desenvolvimento sustentável. Campinas: Editora da Unicamp, São Paulo: Imprensa Oficial, 2001.

FRAGA, G.P.; ABREU, C.A.; MENDES, J. M.B. Poluição do solo e aquífero subterrâneo pela vinhaça infiltrada sob tanques de armazenamento. Sao Paulo; CETESB, 1994.

GOODMAN, D.; REDCLIFT, M. Refashining nature: food, ecology and culture. London/New York: Routledge, 1991.

HARVEY, D. Condição pós-moderna. 4. ed. São Paulo: Edições Loyola, 1994. 
LAMBERT, M. Agricultura e meio ambiente. São Paulo: Ed. Scipione, 1990.

LEFF, E. Epistemologia ambiental. São Paulo, Cortez, 2001.

MACEDO, I.C. (Org.). A energia da cana-de-açúcar. Doze estudos sobre a agroindústria da cana-de-açúcar no Brasil e a sua sustentabilidade. São Paulo: Única, 2005.

MARTINS, R.C. A construção social do valor econômico da água: estudo sociológico sobre agricultura, ruralidade e valoração ambiental no estado de São Paulo. Tese (Doutorado). PPG-SEA, Universidade de São Paulo, 2004.

MARX, K. Para a crítica da economia política. Os pensadores. São Paulo: Nova Cultural, 1987.

MORAES, A. Direito Constitucional. 18a .edição. São Paulo: Atas, 2005.

PNUD. Agenda 21 brasileira. Área temática: agricultura sustentável. Brasília: Ministério do Meio Ambiente. Programa das Nações Unidas para o Desenvolvimento, 1999.

O'CONNOR, J. Capitalism, Nature, Socialism: a theoretical introduction. Capitalism, Nature, Socialism, n. 2, v. 3, October, 1991.

OPPENHEIMER, C. et al. NO2 Emissions from Agricultural Burning in São Paulo, Brazil. Environ. Sci. Technol. v. 38, p. 4557-4561, 2004.

POLLAK, M. L'expérience concentrationnaire. Paris: Éditions Métailié, 2000.

ROCHA, G.A. O grande manancial do Cone Sul. Estudos Avançados, v. 11, n. 30, maio/agosto, 1997.

ROCHA, G. O.; RANCO, A. Sources of atmospheric acidity in a agricultural-industrial region of São Paulo State, Brazil. Journal of Geophysical Research. v. 108, n. D7, 4207, 2003.

RUMIN, C. Trabalho rural e saúde: um estudo das condições de trabalho e sua relação com a saúde dos cortadores de cana no município de Pacaembu/SP. Dissertação de Mestrado. PPG/Medicina Social/USP/Ribeirão Preto, 2004.

SANTOS, M. Metamorfoses do espaço habitado: fundamentos teóricos e metodológicos da geografia. 4ạ ed. São Paulo: Hucitec, 1996.

SÃO PAULO. Relatório de situação dos recursos hídricos do estado de São Paulo. Conselho Estadual de Recursos Hídricos - CRH / Comitê Coordenador do Plano Estadual de Recursos Hídricos - CORHI. São Paulo, 2000.

SILVA, C. A. Promotores de Justiça e novas formas de atuação em defesa de interesses sociais e coletivos. Revista Brasileira de Ciências Sociais, v. 16, n. 45, fevereiro, p. 127-144, 2001. 
SILVA, M. A. M. Errantes do fim do século. São Paulo: Edunesp, 1999.

. "Se eu pudesse, eu quebraria todas as máquinas". In: ANTUNES, R.;

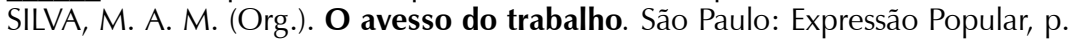
29-78, 2004.

. As venturas e aventuras da sociologia rural no Brasil contemporâneo: relato de uma experiência. Conferência realizada durante 57ạ. Reunião da SBPC, por ocasião do recebimento do Prêmio "Érico Vannucci Mendes", em Fortaleza no dia 19/07/2005.

SILVA, M.A.M. et al. Do karoshi no Japão, à birôla no Brasil: as faces do trabalho no capitalismo mundializado. Nera - Revista Eletrônica do Núcleo de Estudos Pesquisas e Projetos de Reforma Agrária, UNESP Presidente Prudente-SP, vol.8, p.74-108, 2006.

STAHEL, A.W. Time contradictions of capitalism. Capitalism, Nature, Socialism, n. 10, v. 1, MarçO, 1999.

THOMPSON, E. P. Senhores e caçadores. Rio de Janeiro: Paz e Terra, 1987.

WEBER, M. Capitalismo e Sociedade Rural na Alemanha. In: Ensaios de Sociologia. 5. ed. Rio de Janeiro: Zahar Editores, p. 413-437, 1982.

. La situación de los trabajadores agrícolas de la Alemania al este del Elba: visión general. Revista Española de Investigaciones Sociológicas, n. 49, Madrid, enero-marzo, p. 223-55, 1990.

ZAMPERLINI, G. C. M. Investigação da fuligem proveniente da queima de cana-de-açúcar com ênfase nos Hidrocarbonetos policíclicos aromáticos (HPAs). Dissertação de mestrado. PPG/Instituto de Química de Araraquara, 1997.

Recebido: 30/02/2008

Aceite final: 11/08/2008 